\title{
Pengembangan Media Lamat (Laci Matematika) Baby Shark dengan menggunakan Problem Based Learning pada Berhitung Siswa
}

\author{
Erwanti Wahyu ${ }^{1 *}$, Rasiman², Diana Endah ${ }^{3}$ \\ 1,2,3 Jurusan Pendidikan Guru Sekolah Dasar (PGSD), FIP. Universitas PGRI Semarang, Indonesia.
}

\author{
A R T I C L E I N F O \\ Article history: \\ Received 20 August 2018 \\ Received in revised form \\ 9 September 2018 \\ Accepted 15 October 2018 \\ Available online 25 \\ November 2018

\section{Kata Kunci:} \\ Pengembangan, laci \\ matematika, pembelajaran \\ Keywords: \\ development, math drawer, \\ learning
}

\begin{abstract}
A B S T R A K
Penelitian ini bertujuan untuk mengetahui bagaimana mengembangkan media laci matematika yang valid dan mengetahui keberterimaan kepraktisan dalam penggunaan media LAMAT (Laci Matematika) Baby Shark dengan Menggunakan Problem Based Learning Pada Berhitung Siswa Kelas 1 SD bagi Siswa Kelas 1 SDN Karanganyar Gunung 02 Semarang. Penelitian ini menggunakan metodologi penelitian Research and Development (R\&D) dengan langkah pencarian potensi dan masalah, pengumpulan data, desain produk, validasi desain, revisi desain, dan uji coba produk. Rata-rata hasil belajar siswa SDN Karanganyar Gunung 02 Semarang saat pertemuan pertama sebesar 81,53 dan pada saat pertemuan kedua sebesar 73,84. Hasil tanggapan pada analisis ahli media $97,6 \%$ sangat baik, ahli materi $91,4 \%$ sangat baik, angket keberterimaan siswa terhadap media laci matematika baby shark $97,6 \%$ sangat baik. Berdasarkan hasil tersebut dapat disimpulkan bahwa media laci matematika baby shark efektif digunakan dalam pembelajaran matematika karena sudah mencapai hasil belajar saat pertemuan pertama sebesar 81,53 dan pada saat pertemuan kedua sebesar 73,84.
\end{abstract}

\section{A B S T RACT}

This study aims to find out how to develop a valid mathematical drawer media and know the acceptability of practicality in the use of media LAMAT (Drawer Mathematics) Baby Shark by Using Problem Based Learning on Counting Class 1 Elementary School Students for Class 1 Karanganyar Gunung 02 Elementary School Semarang. This research uses Research and Development $(R \& D)$ research methodology with potential and problem search steps, data collection, product design, design validation, design revision, and poduct testing. The average learning outcomes of students at SD Karanganyar Gunung 02 Semarang during the first meeting were 81.53 and at the time of the second meeting it was 73.84. The results of the responses to the analysis of media experts were $97.6 \%$ very good, material experts $91.4 \%$ were very good, the questionnaire of student acceptance of media baby shark math drawers was $97.6 \%$ very good. Based on these results it can be concluded that the baby shark math drawer media is effectively used in mathematics learning because it has achieved learning outcomes when the first meeting was 81.53 and at the second meeting was 73.84. 


\section{Pendahuluan}

Pendidikan tidak bisa lepas dari keseharian, seperti halnya dengan proses berhitung. Sejak dini kita sudah dikenalkan pada masalah matematika seperti mengenal angka hingga berhitung sederhana. Semakin tinggi tingkatan pendidikan maka akan ada masalah-masalah yang muncul sesuai dengan tahapan anak. Setiap anak memiliki kemampuan berbeda-beda dalam memecahkan masalah soal berhitung. Dikarenakan memerlukan latihan dalam berpikir kritis, kreatif serta alternatif. Gunawan (1997) Teori Kemampuan Berhitung Ahli dalam Jurnal http://etheses.uin-malang.ac.id mengungkapkan pelajaran matematika merupakan mata pelajaran yang melatih siswa kritis, kreatif, berpikir alternatif, berargumentasi, menyatakan buah pikirannya baik dalam lisan maupun tulisan secara sistematis, logis dan lugas.

Menurut Sudarman (2007: 69) Problem Based Learning atau pembelajaran berbasis masalah adalah suatu pendekatan pembelajaran menggunakan masalah dunia nyata sebagai suatu konteks bagi peserta didik untuk belajar tentang cara berpikir kritis dan keterampilan pemecahan masalah, serta memperoleh pengetahuan dan konsep esensial dari materi pelajaran. Dalam hal ini, sebagai seorang guru harus mempunyai kiat-kiat khusus untuk mengajar dalam pelajaran matematika. Salah satunya yaitu dengan mengembangkan media pembelajaran untuk konsep berhitung matematika yang abstrak dalam alat yang konkret untuk mempermudah pembelajaran.

Berdasarkan hasil wawancara dengan guru kelas 1 yang dilakukan peneliti di SDN Karanganyar Gunung 02 terdapat beberapa masalah yang ada pada mata pelajaran matematika khususnya materi berhitung. Beberapa masalah yang dihadapi yaitu siswa kurang dalam konsentrasi, kesulitan memahami materi, siswa tidak memperhatikan guru, dan kurangnya penggunaan media pembelajaran. Media pembelajaran yang digunakan hanya dari buku paket dan alat peraga sederhana. Maka yang diperlukan adalah media pembelajaran yang mempunyai tampilan menarik karena dunia anak-anak kelas 1 SD masih bersifat nyata, bagus, unik terlebih jika diberi gambar yang tahapannya sesuai dengan usianya, akan sangat antusias dalam pembelajaran. Karena pada ruang kelas 1 SD belum ada LCD untuk program belajar mengajar maka akan lebih menarik jika media gambar dipadu padankan dengan audio. Analisis kebutuhan siswa, menyatakan bahwa mereka suka berhitung dengan teman (berdiskusi), suka dengan pembelajaran yang ada tampilan menarik gambar dan suara.

Berdasarkan latar belakang diatas, peneliti tertarik untuk mengembangkan penelitian dengan judul Pengembangan Media Lamat (Laci Matematika) Baby Shark Dengan Menggunakan Problem Based Learning Pada Berhitung Siswa Kelas 1 SD. Sesuai dengan rumusan masalah, tujuan yang ingin dicapai penulis melalui penelitian pengembangan ini adalah :Mengetahui kevalidan media LAMAT (Laci Matematika) baby shark pada problem based learning berhitung bagi kelas 1 SD Karanganyar Gunung 02 Semarang. Mengetahui kepraktisan media LAMAT (Laci Matematika) baby shark pada problem based learning berhitung praktis bagi kelas 1 SD Karanganyar Gunung 02 Semarang

Model secara harfiah berarti "bentuk", dalam pemakaian ecara umum model meklakukan interpretasi terhadap hasil observasi dan pengukurannya yang diperoleh dari beberapa sistem. Menurut Agus Suprijono (2011: 45) model diartikan sebagai bentuk representasi akurat sebagai proses aktual yang memungkinkan seseorang atau sekelompok orang mencoba bertindak berdasarkan model itu.

Arends (2016: 36) dalam bukunya Bahan Ajar Pembelajaran Tematik berpendapat bahwa Problem Based Learning membantu siswa mengembangkan keterampilan berpikir dan ketrampilan mengatasi masalah, mempelajari peran-peran orang dewasa dan menjadi pelajar yang mandiri. Guru dituntut dapat memilih model pembelajaran yang dapat memacu semangat setiap siswa untuk secara aktif ikut terlibat dalam pengalaman belajarnya. Salah satu alternatif model pembelajaran yang memungkinkan dikembangkannya keterampilan berpikir siswa (penalaran, komunikasi, dan koneksi) dalam memecahkan masalah adalah Pembelajaran Berbasis Masalah (disingkat PBM).

Menurut Djamarah (1999: 136) dalam bukunya Rostina (2015) menjelaskan di dalam kegiatan belajar mengajar ketidakjelasan bahan yang disampaikan dapat dibantu dengan menghadirkan media sebagai perantara. Sedangkan menurut Mujiono (1994: 31) dalam Rostina (2015) dalam proses belajar mengajar ada empat komponen penting yang berpengaruh bagi keberhsilan belajar siswa, yaitu bahan belajar, suasana belajar, media dan sumber belajar serta guru sebagai subyek pembelajaran.

Media sangat berperan dalam meningkatkan kualitas pendidikan, termasuk untuk peningkatan kualitas pendidikan, termasuk untuk peningkatan kualitas pendidikan matematika. Media pendidikan dapat dipergunakan untuk membangun pemahaman dan penguasaan objek pendidikan. Beberapa media pendidikan yang sering dipergunakan dalam pembelajaran diantaranya media cetak, elektronik, model dan peta (Kreyenbuhl, 1991) dalam Rostina (2015:29). Dengan menggunakan media, konsep dan symbol matematika yang tadinya bersifat abstrak menjadi konkret. Sehingga kita dapat memberikan pengenalan konsep dan simbol matemtika sejak dini, disesuaikan dengan taraf berfikir anaknya. 
Penelitian ini dikuatkan oleh penelitian yang dilakukan sebelumnya oleh Yunin Nurun Nafiah (2016) Menyatakan penerapan PBL dapat meningkatkan hasil belajar siswa sebesar 31,03\%, dan (d) Hasil belajar siswa setelah penerapan PBL yakni jumlah siswa yang mencapai KKM sebanyak 29 siswa (100\%). Marhamah Salehm (2013) menyatakan model PBL sangat efektif dalam memudahkan pemahaman mahasiswa dan menghubungkan pengetahuan mereka dengan realitas permasalahan yang ada dalam masyarakat. Hal senada juga diungkapkan Rizal Abdurrozak (2016) menyatakan berdasarkan hasil penelitian yang dilakukan terdapat peningkatan kemampuan berpikir kreatif siswa dengan menggunakan model PBL. Amelia Dwi Fitri (2016) juga menyatakan bahwa pembelajaran merupakan sesuatu yang diberikan kontekstual (Learning should be a contextual process).

Dalam Teori belajar Piaget tahap-tahap perkembangan kognitif siswa adalah: (1) Tahap sensorimotor (umur 0-2 tahun) Pertumbuhan kemampuan anak tampak dari kegiatan motorik dan persepsinya yang sederhana.Ciri pokok perkembangannya berdasarkan tindakan, dan dilakukan langkah demi langkah. (2) Tahap preoperasional (umur 2- 7 tahun) Perkembangan yang pesat dialami oleh anak pada tahap ini.Anak semakin memahami lambang-lambang bahasa yang digunakan untuk menunjukkan benda-benda. Keputusan yang diambil hanya berdasarkan intuisi, bukan atas dasar analisis rasional. (3) Tahap operasional konkret (umur 7-11 tahun)Tahap ini anak mulai berpikir lofis dan sistematis untuk mencapai pemecahan masalah.Masalah yang dihadapi dalam tahap ini bersifat konkret. Anak akan merasa kesulitan bila menghadapi masalah yang bersifat abstrak. Pada tahap ini anak menyukai soal-soal yang telah tersedia jawabannya. (4) Tahap operasional formal (umur 11-15 tahun) Anak mencapai tahap yang ditandai dengan pola pikirnya yang seperti orang dewasa. Anak telah dapat menerapkan cara berfikir terhadap permaslahan yang konkret maupun abstrak.

\section{Metode}

Penelitian ini menggunakan penelitian dan pengembangan Research and Development (R\&D). Research and Development merupakan metode penelitian yang digunakan untuk menghasilkan produk tertentu, dan menguji keefektifan produk tertentu (Sugiyono 2011: 407). Peneliti memilih jenis R \& D karena dalam penelitian ini peneliti ingin mengembangkan suatu media pembelajaran yang bernama Laci Matematika. Media tersebut merupakan pengembangan dari media pembelajaran penggunaan corong berhitung, jadi Laci Matematika sendiri merupakan sebuah laci matematika dengan menggunakan desain 3 dimensi gambar babyshark yang menggabungkan media audio visual juga terdapat soal berhitung pada atas papan tersebut. Media ini dikembangkan untuk digunakan pada berhitung kelas 1 konsep penjumlahan dan pengurangan serta akan diuji keefektifannya.

Prosedur penelitian pengembangan yang digunakan mengacu pada pengembangan Borg and Gall. Menurut Borg and Gall dalam buku Nana Syaodih (2016: 190), penelitian pengembangan terdiri dari 10 langkah pengembangan yaitu : Melakukan penelitian pendahuluan dan pengumpulan data awal, melakukan perencanaan, mengembangkan produk awal, melakukan uji coba lapangan tahap awal, melakukan revisi terhadap produk utama, melakukan uji coba lapangan utama, melakukan revisi terhadap produk operasional, melakukan uji lapangan operasional, melakukan perbaikan terhadap produk akhir, mendiseminasikan dan mengimplementasikan produk

Berdasarkan keputusan hasil rapat senat Fakultas, diputuskan bahwa mahasiswa Strata 1 (S1) yang melakukan penelitian dan pengembangan hanya sebatas pada tahap empat atau ke lima yaitu hanya sebatas uji coba lapangan awal dan revisi hasil uji coba berdasarkan analisis uji coba lapangan awal. Media LAMAT (Laci Matematika) Baby Shark Dengan Menggunakan Problem Based Learning Pada Berhitung Siswa Kelas 1 SD ini adalah media yang berbentuk laci matematika 3 dimensi yang terdapat corong untuk isian, amplop permasalahan sebagai soal serta jawaban dalam bentuk menempel angka. Juga terdapat audio dengan lagu apersepsi Baby Shark disetiap awalan menyelesaikan suatu permasalahan.Media Laci Matematika Baby Shark ini bertujuan untuk mempermudah menyelesaikan soal berhitung maupun pengaplikasian soal cerita dalam mengikuti pembelajaran matematika materi berhitung serta kepraktisan memahami materi yang dipelajari.

Pengembangan yang peneliti lakukan adalah yang pertama mencari potensi dan masalah,selanjunya langkah kedua yaitu peneliti mengumpulkan data. Berdasarkan analisis kebutuhan yang ada di lapangan, peneliti mengembangkan sebuah media pembelajaran LAMAT (Laci Matematika) Baby Shark Dengan Menggunakan Problem Based Learning Pada Berhitung Siswa Kelas 1 SD yang dikembangkan berdasarkan ide dari peneliti dan sebagai alternatif penggunaan media pembelajaran berbentuk laci matematika yang dapat membantu pendidik dan peserta didik di dalam kelas. Desain Laci Matematika Baby Shark ini berukuran $80 \mathrm{~cm}$ x $33 \mathrm{~cm}$ x $30 \mathrm{~cm}$ dengan menggunakan triplek yang dilapisi kain flannel dan terdapat audio dibelakang laci tersebut. Data mengenai kelayakan media didapatkan dari validator ahli media. 
Hasil pertemuan pertama menunjukkan nilai terendah 40 dan nilai tertinggi 100, yang tidak mencapai KKM berjumlah 9 siswa dengan presentase 34,61\%, sedangkan yang mencapai KKM berjumlah 17 siswa dengan presentase 65,38\%, dari hasil pertemuan pertama tersebut diperoleh nilai rata-rata sebesar 81,53. Dari hasil pertemuan kedua menunjukkan nilai terendah 40 dan nilai tertinggi 100, terdapat 13 siswa tidak mencapai KKM dengan pesentase 50\% dan 13 siswa mencapai KKM dengan presentase 50\% dengan nilai rata-rata 73,84. Hasil presentase angket siswa yaitu 97,6\% dengan kriteria sangat baik. Pokok temuan yang dihasilkan dalam penelitian pengembangan ini adalah sebagai berikut :

Dihasilkan produk pengembangan berupa media pembelajaran LAMAT (Laci Matematika) Baby Shark Dengan Menggunakan Problem Based Learning Pada Berhitung Siswa kelas 1 SD yang valid untuk digunakan sebagai media pembelajaran di kelas 1 semester 1 . Hasil validasi yang dilakukan oleh ahli media menunjukkan presentase 97,6\% dengan kriteria sangat baik dan hasil dari validasi materi dengan presentase 91,4\% dengan kriteria sangat baik. Penggunaan media LAMAT (Laci Matematika) Baby Shark Dengan Menggunakan Problem Based Learning Pada Berhitung Siswa kelas 1 SD praktis digunakan dalam pembelajaran materi berhitung kelas 1 Sekolah Dasar

\section{Hasil dan Pembahasan}

Laci Matematika Baby Shark dikembangkan berdasarkan langkah-langkah penelitian dan pengembangan.Model ini digunakan untuk menghasilkan dan menguji produk tertentu. Media LAMAT (Laci Matematika) Baby Shark Dengan Menggunakan Problem Based Learning Pada Berhitung Siswa kelas 1 SD dibuat untuk menghasilkan produk berupa media pembelajaran.

Tabel 1. Hasil Penilaian Ahli Media

\begin{tabular}{llrrrr}
\hline No & Aspek Penilaian & Jumlah Skor & Skor Ideal & Presentase & Kriteria \\
\hline 1 & Desain Produk & 44 & 45 & $97,7 \%$ & Sangat Baik \\
2 & Kualitas Produk & 24 & 25 & $96 \%$ & Sangat Baik \\
3 & Teknik Penggunaan & 15 & 15 & $100 \%$ & Sangat Baik \\
& Jumlah Skor & 83 & 85 & $97,6 \%$ & Sangat Baik \\
\hline
\end{tabular}

Berdasarkan perhitungan tabel 4.1, maka diketahui presentase sebesar 97,6 \% dikategorikan sangat baik.

Tabel 2. Hasil Penilaian Ahli Materi

\begin{tabular}{llcccc}
\hline No & Aspek Penilaian & Jumlah Skor & Skor Ideal & Presentase & Kriteria \\
\hline 1 & Indikator Kompetensi & 27 & 30 & $89,9 \%$ & Sangat Baik \\
2 & Penggunaan Konsep & 12 & 15 & $80 \%$ & Baik \\
3 & Manfaat produk & 25 & 25 & $100 \%$ & Sangat Baik \\
& Jumlah Skor & 64 & 70 & $91,4 \%$ & Sangat Baik \\
\hline
\end{tabular}

Berdasarkan perhitungan angket tanggapan 26 siswa diatas, maka diperoleh presentase sebesar 97,6\% dengan kriteria sangat baik. Berdasarkan presentase dari hasil pertemuan pertama, kedua, analisis ahli media dan ahli materi serta angket tanggapan siswa terlihat bahwa presentase yang dihasilkan termasuk pada kriteria sangat baik sehingga dapat disimpulkan bahwa media LAMAT (Laci Matematika) Baby Shark Dengan Menggunakan Problem Based Learning Pada Berhitung Siswa kelas 1 SD valid dan praktis digunakan untuk media pembelajaran berhitung di kelas 1. Media LAMAT (Laci Matematika) Baby Shark juga efektif digunakan untuk meningkatkan konsentrasi dan keaktifan siswa dalaam kegiatan pembelajaran serta meningkatkan minat belajar siswa.

Model pembelajaran Problem Based Learning Pada Berhitung Siswa kelas 1 SD secara umum bisa dikatagorikan dengan kriteria sangat baik. Penelitian ini didukung pula oleh penelitian yang dilakukan oleh Yunin Nurun Nafiah (2014) dengan judul Penerapan Model Problem Based Learning Untuk 
Meningkatkan Keterampilan Berpikir Kritis Dan Hasil Belajar Siswa dengan hasil penilaian menunjukkan peningkatan penilaian pada aspek aspek yang sebelumnya masih kurang. Berdasarkan rekapitulasi data diperoleh nilai tertinggi 88,18 , nilai terrendah 78,38 , nilai rata-rata 83,2 . Penelitian yang senada juga dilakukan oleh Bekti Wulandari (2013) dengan penelitian yang berjudul Pengaruh Problem-Based Learning Terhadap Hasil Belajar Ditinjau Dari Motivasi Belajar PLC Di SMK. Hasil dari penelitian ini adalah Terdapat perbedaan hasil belajar yang signifikan antara siswa yang diajar dengan metode PBL dengan siswa yang diajar dengan metode pembelajaran demonstrasi ditinjau dari motivasi siswa. Ditinjau dari siswa yang memiliki motivasi tinggi, hasil belajar antara siswa yang diajar dengan metode Problem Based Learning lebih tinggi dibandingkan dengan siswa yang diajar dengan metode pembelajaran demonstrasi. Ditinjau dari siswa yang memiliki motivasi rendah, hasil belajar antara siswa yang diajar dengan metode PBL lebih tinggi dibandingkan dengan siswa yang diajar dengan metode pembelajaran demonstrasi.

Berdasarkan hasil secara empiris dan penelitian yang mendukung hasil penelitian ini dapat disimpulkan bahwa model pembelajaran Problem Based Learning bisa di terapkan dalam semua mata pelajaran baik untuk mengukur hasil belajar maupun kemampuan yang lain. Disamping itu model pembelajaran Problem Based Learning juga bisa diinovasikan dengan teknik - teknik pembelajaran yang lain seperti dalam penelitian ini adalah menginovasikan model pembelajaran Problem Based Learning dengan Pengembangan Media Lamat (Laci Matematika) Baby Shark yang secara khusus mengukur kemampuan berhitung siswa kelas $1 \mathrm{SD}$.

\section{Simpulan dan Saran}

Pengembangan media LAMAT (Laci Matematika) Baby Shark Dengan Menggunakan Problem Based Learning Pada Berhitung Siswa kelas 1 SD. Hasil validasi oleh ahli media diperoleh presentase sebesar 97,6\% dengan kriteria sangat baik, hasil validasi oleh ahli materi diperoleh presentase sebesar 91,4\% dengan kriteria sangat baik dan angket tanggapan siswa SDN Karanganyar Gunung 02 Semarang dengan presentase $97,6 \%$.

Penggunaan media LAMAT (Laci Matematika) Baby Shark Dengan Menggunakan Problem Based Learning Pada Berhitung Siswa kelas 1 SD praktis melihat dari hasil nilai dari pertemuan pertama dan kedua dengan rata-rata hasil belajar sebesar 81,53 dengan ketuntasan sebesar 65,38\% dan pertemuan kedua dengan rata-rata hasil belajar sebesar 73,84 dengan ketuntasan sebesar 50\%.

Berdasarkan hasil penelitian yang diperoleh, maka peneliti memberikan saran sebagai pertimbangan untuk perbaikan media dan kegiatan pembelajaran sebagai berikut: (1) Bagi Kepala Sekolah diharapkan mampu mendukung guru dalam melaksanakan pembelajaran dengan menggunakan media pembelajaran LAMAT (Laci Matematika) Baby Shark, (2) Bagi Guru Pemanfaatan media LAMAT (Laci Matematika) Baby Shark oleh guru diharapkan dapat dikembangkan pada bahasan model pembelajaran lain agar dapat mengembangkan pemahaman siswa, (3) Bagi Peneliti Mendatang Perlu adanya penelitian lebih lanjut mengenai media LAMAT (Laci Matematika) Baby Shark dari tahap keenam hingga tahap kesepuluh.Menerapkan konsep berhitung yang berbeda sehingga menghasilkan media yang lebih inovatif dan berkualitas. Perlu adanya penelitian lebih lanjut pada konsep dan pengembangan audio sehingga lebih bervariatif

\section{Daftar Rujukan}

Amelia Dwi Fitri. 2016. Penerapan Problem Based Learnin (Pbl) Dalam Kurikulum Berbasis Kompetensi. JAMBI MEDICAL JOURNAL Jurnal Kedokteran dan Kesehatan. Vol 4. No1.

Gunawan. 1997. Teori Kemampuan Berhitung Ahli dalam Jurnal. http://etheses.uin-malang.ac.id

Ibrahim, B., Erdal, S., Mustafa, S (2009). The effect of problem-based leraning instruction on university students' perfermance of conceptual and quantitative problems in gas concepts.Eurosia Jurnal of Mathematics, Science \& Technology Education, 5(2), 153-156

Marhamah Saleh. 2013. Strategi Pembelajaran Fiqh dengan Problem-Based Learning. Jurnal Ilmiah DIDAKTIKA. VOL. XIV NO. 1, 190-220.

Nurun Nafiah,Yunin. 2014. Penerapan Model Problem Based Learning Untuk Meningkatkan Keterampilan Berpikir Kritis Dan Hasil Belajar Siswa. Jurnal Pendidikan Vokasi, Vol 4, Nomor 1.

Rizal Abdurrozak, Asep Kurnia Jayadinata, Isrok 'atun. 2016. Pengaruh Model Problem Based Learning 
Terhadap Kemampuan Berpikir Kreatif Siswa. Jurnal Pena Ilmiah: Vol. 1, No, 1.

Rostina. 2015. Media dan Alat Peraga dalam pembelajaran Matematika. Bandung: Penerbit Alfabeta

Sudarman. 2007. "Problem Based Learning: Suatu Model Pembelajaran untuk Mengembangkann dan Meningkatkan Kemampuan Memecahkan Masalah". Jurnal Pendidikan Inovatif Vol.2 No.2, pp.68-73

Sugiyanto. 2010. Model-Model Pembelajaran Inovatif. Surakarta: Yuma Pustaka

Sugiyono. 2011. Metode Penelitian Kuantitatif, Kualitatif, dan R\&D. Bandung: Alfabeta, cv.

Suharmanto. 2014. Pengembangan Media Pembelajaran Papan Hitung Pembagian Pada Mata Pelajaran Matematika Sekolah Dasar Kelas 2. Jurnal : FIP UNY

Sukmadinata, Nana Syaodih. 2016. Metode Penelitian Pendidikan. Bandung: PT Remaja Rosdakarya

Triyanto. 2009. Pengembangan Model Pembelajaran Tematik. Jakarta: PT Prestasi Pustakaraya

Wulandari,Bekti. 2013. Pengaruh Problem-Based Learning Terhadap Hasil Belajar Ditinjau Dari Motivasi Belajar PLC di SMK. Jurnal Pendidikan Vokasi, Vol 3, Nomor 2.

Yunin Nurun Nafiah, Wardan Suyanto. 2016. Penerapan Model Problem-Based Learning Untuk Meningkatkan Keterampilan Berpikir Kritis Dan Hasil Belajar Siswa. Jurnal Pendidikan Vokasi UNY. Vol 1 No 2. 